\title{
Implementation of Marriage Registration in Aceh Qanun Number 6 of 2008 concerning Administrative Registration (Analysis of Illegal Marriage Practices in Lhoksukon District, North Aceh Regency)
}

\author{
Teuku Islahuddin ${ }^{1}$, Dhiauddin Tanjung ${ }^{2}$, Ramadhan Syahmedi Siregar ${ }^{3}$ \\ 1,2,3 Universitas Islam Negeri Sumatera Utara, Indonesia \\ Email: teukuislahuddin1@gmail.com
}

\begin{abstract}
The implementation of Aceh Qanun Number 6 of 2008 Regarding Marriage Registration in Lhoksukon North Aceh, if analyzed based on the theory of legal effectiveness, is considered not maximally effective, even though this qanun has been enforced since 2018 and marriages carried out with wild qadhi. In addition, there are still many couples who submit Isbat Nikah to the Syar'iyah Court cannot prove their marriage at the time of examination in court. Legally, this qanun is very good. From the aspect of law enforcement, it still has weaknesses because the socialization carried out has not had a significant impact on the community, and the infrastructure is considered adequate, but from the aspect of public awareness it is still very low. Qanun Number 6 of 2008 concerning the Implementation of Population Administration relating to the registration of marriages is stated in several articles, namely Article 3, where the purpose of registering marriages is to ensure the legal status of each resident; protection of the rights of the population; ordered population administration; management of population administration information; and guarantee services for the rights of the population. Marriage registration is more firmly and specifically stated in Article 55 and Article 56. Article 55: (1) Every marriage, whether for residents who are Muslim or other religions, must be recorded. (2) Marriage registration for residents who are Muslim as referred to in paragraph (1) is carried out by marriage registrar employees at the District Religious Affairs Office. (3) The registration of marriages for residents of other religions as referred to in paragraph (1) is carried out by officials of the Regency/Municipal Population and Civil Registry Office. (4) The marriage registrar at the District Office of Religious Affairs shall record the marriage on the Marriage Certificate and issue the Marriage Certificate Quotation. (5) The Civil Registration Officer shall record marriages on the Marriage Certificate Registry and issue a Marriage Certificate Quotation. (6) Data on the results of marriage registration must be submitted by the District Office of Religious Affairs to the Regency/Municipal Population and Civil Registry Service within 10 (ten) days after the marriage registration is carried out. Article 56: Marriage registration as referred to in Article 55 also applies to: a) marriages determined by the court/Shari'ah Court; b) marriages of foreign nationals conducted in Aceh at the request of the foreign nationals concerned.
\end{abstract}

Keywords: Implementation; marriage; qanun

\section{Introduction}

The implementation of Aceh Qanun Number 6 of 2008 concerning marriage registration is the implementation of a regulation in life. When discussing regulations regarding marriage registration, it means talking about the effectiveness of the law in regulating or forcing people to obey the law. The effectiveness of the law in question means reviewing the legal rules that must meet the requirements, namely: apply juridically, apply 
sociologically, and apply philosophically. Therefore, the factors that can influence the function of the law in society are:

1. The rule of law or regulation itself. The legal rules that underlie Aceh Qanun No. 6 of 2008 concerning marriage registration are Islamic legal principles sourced from the Qur'an, hadith and statutory regulations regarding marriage registration.

2. Law enforcement officers or officers, The law enforcer in terms of regulations regarding marriage registration is the Office of Religious Affairs (KUA).

3. Facilities and infrastructure (facilities) used by law enforcement, facilities and infrastructure in the registration of marriages, are intended for everything related to physical needs, such as marriage counselors, executors of marriage registration and the Office of Religious Affairs (KUA).

4. Citizen's awareness in the field of legal culture, namely the legal awareness of the community itself.

5. Cultural factors, including the existence of customary law that applies in society with certain systems and patterns, or the emergence of differences in views in society due to certain influences.

In accordance with the theme and purpose of this research, the theory used is the sociology of law theory, where this legal theory is related to the type of empirical legal research, which examines the relationship between law and social behavior. In the sociology of law known as structural theory. From the application of this basic structure theory, several legal conclusions can be drawn which can be categorized as follows:

1. In the field of law enforcement, often positive legal instruments, such as laws that are advanced and modern, but when these legal instruments are enforced, they do not produce good output (meaning that the implementation has not been properly and properly optimized), where justice is not achieved, the certainty of law and order is also far from expectations. This is caused by various factors such as the low quality of law enforcers. This phenomenon that occurs on the Veranda of Mecca is in accordance with the theory of structure where people still ignore Qanun Number 6 of 2008 especially regarding marriage registration.

2. In the field of legal culture, namely the legal awareness of the community itself, legal culture or better known as legal awareness of a nation is difficult to change because the legal culture and legal awareness directly touch the basic structure of the legal field in a society.

Systematically, Qanun Number 6 of 2008 concerning Implementation of Population Administration consists of XVII chapters and 96 articles. Seventeen chapters in orderQanun Number 6 of 2008 concerning The implementation of Population Administration contains: General Provisions, Principles and Objectives, Aceh Residents, Residents' Rights and Obligations, Aceh and District/City Government Authorities, Population Identification Number (NIK) and Temporary Resident Identity Number (NIPS), Population Registration, Civil Registration, Population Registration and Civil Registration When Aceh is in an Emergency and Extraordinary State, Population Administration Information System, Population Data and Documents, Protection of Population Data and Documents, Financing, Administrative Sanctions, Criminal Provisions, Transitional Provisions, and Closing Provisions.

Marriage is a legal actwhich results in the validity of a relationship between a man and a woman, the validity of a marriage will have an impact on the legal consequences after the marriage. The validity of marriage in Law Number 1 of 1974 is contained in Article 2 
paragraph (1) which explains, that: "marriage is legal if it is carried out according to the law of each religion and belief".

From this sentence, Law Number 1 of 1974 requires a marriage to be valid if two things are fulfilled, namely the conditions according to the provisions of their respective religions and the procedures required by state law without regard to these provisions, the marriage is invalid.

Everyone who wants to get married must meet the requirements and pillars of marriage. In addition, Article 2 paragraph (2) of Law Number 1 of 1974 concerning Marriage states that "Every marriage is recorded according to the applicable laws and regulations". All events that occur in the family that have legal aspects need to be recorded and recorded, so that both the person concerned and other interested parties have authentic evidence about the event, thus the legal position of a person becomes firm and clear.

The function and benefit of registering a marriage is for authentic evidence if a problem occurs in a marriage, for example determining the status of a child born in a marriage between the couple and in the event of a divorce, the marriage certificate is used as evidence and a tool in resolving it. So it can be concluded that marriages without registration are invalid under Indonesian positive law.

Currently unregistered marriages have become a problem that continues to be debated in society besides unregistered marriages, especially in Aceh, currently there are so many marriages using illegal qadhi so this has a negative impact. Because it will result in the invalidity of the marriage, because marriages carried out in illegal qadhi are not recorded so that the husband and wife do not have a valid marriage book.

Based on the results of research so far, there have been several marriages using illegal qadhi in Aceh, especially in Lhoksukon, North Aceh. Marriages with illegal qadhi are generally carried out by the Lhoksukon community, not only for the first marriage, but also for the second marriage, or the third time by divorcing the second time and so on whose motivation is more for sexual satisfaction.

Among the Lhoksukon people, illegal marriages occur in two forms: first, the marriage contract is not registered and registered with the KUA by the bride and groom or by their parents, but in the implementation of the wedding procession they continue to follow and guide the fiqh of munakahat as understood from the scholars or the existing tenungku, namely the existence of two brides, there is a lineage guardian, the consent and qabul, the dowry and the presence of two witnesses. The second marriage is done without presenting a guardian, or because the female guardian does not agree, or just because she wants to satisfy her lust without paying attention to the provisions of the Shari'a. Sometimes marriages are carried out without presenting a guardian because the lineage guardian was not notified, or the lineage guardian was not presented for fear of not giving permission and approval.

Marriage on wild qadli can be concluded as marriage without a guardian, marriage without witnesses, marriage that does not fulfill syurut an-nikah (requirements for marriage) and does not fulfill arkan annikah (pillars of marriage). Such marriage is not legal, both from The syar'i side and from the statutory regulations. This kind of marriage is no different from engineered adultery. 
In classical figh, the terminology of illegal marriage is unknown, as well as among the penghulu. KUA as the Marriage Registrar does not recognize the term qadhi wild KUA only recognizes two kinds of marriages in accordance with the National Marriage Law, namely registered and unregistered marriages. In general, KUA does not want to accept the practice of marriage to illegal qadhi, even if there is only a consultation. This is because the Marriage Registrar (PPN) or the penghulu will be subject to a prison sentence if they legitimize illegal marriages. In other words, the KUA will not be responsible if the legal consequences will harm the interested parties in the future, meaning that the risk must be borne by the individuals concerned.

Even in society, KUA does not tolerate illegal qadhi marriages, but this phenomenon arises and develops secretly in some people, even becoming a trend in the current era. Marriage using the services of this wild qadhi has reached a very alarming stage. Getting married using the services of a wild qadhi at this time is to make negative things such as for infidelity, marrying so that their superiors at the office don't know about it and other things in the context of negative actions. So far, the marriage using the services of the wild qadhi has had a negative effect on the couple. Like the legalization of child status, the Islamic Court does not accept requests for Isbat Nikah from couples who marry using the services of the illegal qadhi.

In addition, couples who apply for Isbat Marriage to the Sharia Court could not prove her marriage at the time of examination at the trial, because the wild qadhi as a witness in the trial who married the couple also did not want to be present to provide information so that the application was rejected. Many married couples use the services of illegal qadhi who apply to the Sharia Court, to legalize marriage, that's where the couple found out that it was wrong to marry a wild qadhi. As happened to the couple with the initials SL and who got married in one of the Islamic boarding schools in the Lhoksukon area. The couple wants to apply for Istbat marriage to the Sharia Court for the legalization of marriage in order to make their child's birth certificate. However, because the couple married through illegal qadhi services, it was difficult for them to obtain a marriage certificate so that the couple did not have legality.

So far, marriage using the services of a wild qadhi is considered by the couple to be easy and cheap. And marriages using the services of these wild qadhis have mushroomed and have become a covert and well-organized business. Some of the reasons for the wild qadhi to marry off the couple is to avoid committing adultery. This wild qadhi exists and continues to exist because of demand. Marriage actors who use illegal qadhi services are no longer limited to ordinary people, but have involved a number of circles, community leaders from the upper middle class to practice polygamy because of the absence of permission from the first wife.

In some cases, the point is that couples who marry using illegal qadhi services are couples who do not meet the requirements for marriage and do not want to follow the mechanism regulated by the KUA. Conditions that are not completed such as the absence of blessing from parents, polygamy, and so on that do not meet the requirements of marriage.

Based on the laws and regulations, marriage through illegal qadhi is not valid. Because marriage through wild qadhi does not follow the procedures that have been determined by the State and Religion.The Compilation of Islamic Law also emphasizes that legal marriages are not only carried out according to religious law but also in accordance with the laws governing marriage in a country. The registration of the marriage provides legal protection not only for those who carry out the marriage, but also on their children and assets obtained after the marriage until the marriage is dissolved, whether it is due to divorce or death. 
For wild qadhi, marrying people is a business, because it has become one of their livelihoods. Those who get the nickname as wild qadhi are generally people who get the title of ustador tengku or people claiming to be clerics or tengku. This kind of marriage, besides being illegal according to religious teachings, is also considered to have no legal force (no legal force) by the State. In Indonesia, such marriages are not protected by law.

In many cases in the field, especially in Lhoksukon, North Aceh, marriages with illegal qadhis are carried out without paying attention to the problem of marriage guardians, as data found that many prospective couples come to wild qadhis asking to be married but do not present marriage guardians. In other cases, the marriage guardian is the person who has been provided and appointed by the wild qadhi, whose appointed marriage guardian has no kinship with the prospective bride.

Marriage to this wild qadhi is clearly invalid, because the guardian does not comply with religious provisions. Besides the marriage guardian is not valid, the marriage contract (ijab qabul) is also invalid because the one who does the consent must be the marriage guardian in accordance with religious rules. The fatal consequence of this kind of marriage is that because the witness and the qabul are invalid, the marriage cannot justify what has been forbidden for the couple to do husband and wife.

First, the economic factor. One of the economic factors is the administrative costs of registering marriages, namely some people, especially those of the lower middle class, feel unable to pay for the administration of registration, which sometimes swells to twice the official cost as expressed by Fatimah, that marrying using the services of a wild qadhi is costeffective. There are complaints from the public that the cost of registering marriages at KUA is not transparent, how much is the actual cost normatively. Therefore, in the practice of people who carry out marriages, various fees are charged.

Second, pregnant out of wedlock, as the effect of promiscuity. The result of promiscuity between men and women, who no longer heed the norms and religious rules is the occurrence of pregnancy outside of marriage. Pregnancy that occurs outside of marriage is a disgrace to the family which will invite ridicule from the community. Because of this, parents then marry off their daughters to the man who impregnated her on the grounds of saving the family's good name and without involving the VAT officer, but only by illegal qadhis without recording.

Third, the lack of public understanding and awareness about marriage registration. With a very minimal understanding of the community about the importance of recording marriages, as a result, it affects people to continue to carry out marriages using the services of illegal qadhi. There is an assumption that marriages that are recorded and not recorded are the same. In fact, marriage using the services of a wild qadhi is not valid because the guardian is not clear, while the guardian is one of the pillars of marriage.

Fourth, prolonged cheating, basically to avoid adultery and it is difficult to get permission from the wife so that they do illegal marriages using the services of wild qadhi. Even though this act will damage the household that has been built with the first wife and then the second wife who is married to a wild qadhi is harmed and the marriage is invalid. So if this is done, the marriage will be said to be adulterous because one of the pillars is not fulfilled. 
Fifth, not getting permission to practice polygamy. Based on these reasons, the husband took a shortcut to marry using the services of a wild qadhi. It is very unfortunate that this misunderstanding to carry out a marriage with a wild qadhi is not valid. Because it is not the same as a sirri marriage. Sirri marriages are legal according to religion, but they are not registered.

Sixth, do not have a guardian. The reason for not having a guardian is for example the guardian does not agree to the marriage, for example the prospective husband already has a wife and children. In addition, the guardian does not agree for various reasons so they are reluctant to marry. And this is one of the factors that often occurs in society, usually this is a young couple.

Seventh, avoiding administrative procedures. This reason is considered by couples who marry illegally because of complicated administration and long time. Even though this is a very important administrative matter in order to obtain legal certainty so that the couple will not have legal problems later.

Eighth, is to avoid adultery. This reason is the most common. Even though we can understand inner and outer marriage so it cannot be considered only an inner relationship. In addition, as explained above, illegal marriages are illegal. This adultery cannot be used as a reason for illegal marriage for couples who want to marry for that reason. If it is done it will make a prolonged adultery.

In addition, the long-term effects of the Aceh conflict also made a factor that prevented marriages in Aceh from being registered. During the Aceh conflict in the 80s and 90s, many KUAs in the sub-district were burned so that marriages could not be recorded at the KUA, so this has become a problem in itself until now. Currently, illegal marriages using the services of illegal qadhis add to the problems of marriage in Aceh.

Basically, marriage using the services of a wild qadhi is considered easy, not difficult and cheap. Even though the effects of marriage have never been considered in the future, both legally legally and legally legally. Many problems in the field occur along with the birth of their child where the child's status is not clear later. That's where it started to get really difficult for parents who got married using the services of wild qadhi. So that at that time only made legal efforts.

\section{Review of Literatures}

\section{Lhoksukon Community Views On Wild Marriage Practices}

In the Lhoksukon community, one form of marriage that is carried out is Sirri marriage or illegal marriage, namely marriages that are carried out secretly, some are recorded but hidden from the community and some are not registered with the Marriage Registrar $(\mathrm{PPN})$ and are not registered at the Office of the Registrar. Religious Affairs (KUA). Marriage like this is not in accordance with the hadith of the apostle where the apostle ordered the married people to announce their marriage to walimah (kenduri udep / thanksgiving).

Several community leaders in Lhoksukon, North Aceh district, expressed their disapproval of the illegal marriage practice. These community leaders are representatives of the ulama, intellectuals/academics and other community leaders such as village officials and Tuha Peut gampong. They stated that indeed in Islam or fiqh, marriage registration is not a requirement for a valid marriage. Marriage registration is only recommended with the aim of 
realizing administrative order, but if a marriage is illegal without fulfilling the requirements and especially the pillars of marriage, it will be an act that is religiously forbidden and prohibited by the state. Therefore, the marriage should be carried out legally and in an orderly manner by registering the marriage with the local PPPN or KUA marriage registrar.

According to them, the government really needs to make regulations and strict sanctions against couples who do illegal marriages, as well as illegal qadhis who practice illegal marriages. Giving legal sanctions to those who practice illegal marriages is a necessity for the benefit of married couples, the benefit of the household, the benefit of the marriage institution, so that all legal consequences of a marriage carried out can realize a marriage that is in accordance with the purpose of the marriage itself, namely forming a house. a happy and eternal household or family based on the One Godhead as affirmed in Law no. 1 of 1974, or realizing a sakinah mawaddan and rahmah household as per the perspective of the Compilation of Islamic Law.

Furthermore, the people of Lhoksukon revealed that the deterrent effect of imposing criminal sanctions on perpetrators of illegal marriages is very appropriate and has great benefits in an effort to minimize the prevalence of illegal marriages that allow for marriages that are disguised as adultery. Besides that, the imposition of sanctions on perpetrators of illegal marriages can be a lesson for other people not to do the same thing, as the imposition of sanctions against adultery jinayah which is snared with caning and must be carried out in front of the general public according to the provisions of jinayah fiqh. This can then reduce the number of illegal marriages that occur in Lhoksukon, North Aceh Regency.

Based on the views of other people, it was also revealed that, there are some people who do not agree with the sanctions against perpetrators of illegal marriages. They said, "If sanctions are given to perpetrators of illegal marriages and the sanctions are actually implemented, it can have bad consequences. Precisely the perpetrators of illegal marriages will tend to get together and there must also be clear rules, which actions deserve punishment and which do not. According to them, a clear distinction must be made between illegal marriages that are not religiously legal, and those that are not legal according to the rules of the marriage law, with unregistered marriages which are only not carried out at the KUA, are not recorded by the PPN, but are legal according to religious provisions because of the fulfillment of the terms and pillars of marriage based on religious teachings or fiqh.

\section{Discussion}

\section{Efforts To Minimize Understanding Marriage Through Marriage Registration At Kua Lhoksukon, Utara Aceh}

The phenomenon of unregistered marriages and illegal marriages in Lhoksukon is still fairly large, there are so many factors that encourage the Lhoksukon people to carry out unregistered marriages or underhand marriages. Some people still believe that a sirri marriage is considered valid according to Islamic law if it has fulfilled the pillars and conditions of marriage, even though the marriage is not officially registered. Vice versa, a divorce is considered valid if it has fulfilled the pillars and conditions, even though the divorce was carried out outside the court or outside the Syar'iyah Court.

In the perspective of fiqh, a marriage is considered valid if it has fulfilled the pillars and conditions of marriage which include the prospective groom, prospective bride, guardian of the bride, two witnesses and qabul consent. Meanwhile, according to the marriage law, in 
addition to fulfilling the rules of marriage, it must be recorded by a marriage registrar. If the marriage is not registered, it is called an illegal marriage.

Materially, an underhand marriage is legal because the requirements for marriage according to Islamic law have been fulfilled, but legally it does not meet the requirements of the provisions stipulated in the Marriage Law and its implementing regulations, so it can be considered invalid before the law. As stated in Article 2 paragraphs (1) and (2) of Law Number 1 of 1974 which reads:

"Marriage is legal if it is carried out according to the law of each religion and belief. Every marriage is recorded according to the applicable laws and regulations. This of course gives an illustration for us that every underhanded marriage has an obligation for the bride and groom to register their marriage at the Ministry of Religion where they hold their marriage. In connection with the above, until now, legal theorists and practitioners still have disagreements about the juridical understanding of the validity of a marriage.

There are two opinions of legal experts on this matter: a) That a marriage is valid only to fulfill article 2 paragraph (1) of the marriage law, that is, the marriage has been carried out according to the provisions of Islamic law perfectly (fulfilling the pillars and conditions of the law). conditions for marriage which are generally considered standard by the Islamic world. Regarding marriage registration by VAT, it is not a requirement for a valid marriage, but only an administrative obligation. b) That a marriage contract is valid must meet the provisions of the Marriage Law article 2 paragraph (1) regarding religious procedures and paragraph (2) regarding the simultaneous registration of the marriage by the PPN. Thus, the provisions of paragraphs (1) and (2) are cumulative conditions, not alternatives. Therefore, marriages carried out according to the provisions of Islamic law without recording by VAT, is not considered a legal marriage. And it was this marriage which was later known as "underhand marriage".

There is no text in the Qur'an or sunnah which regulates the recording of marriages, but the Qur'an and pay great attention to the recording of every debt transaction and sale and purchase. It should be that in muamalah matters such as debts, recording is ordered, especially in marriages that will give birth to other laws such as child custody rights, inheritance rights and other rights. Therefore, complying with religious rules and state regulations is very important because we are not only religious but also citizens, so that household travel does not only come into contact with religious rules but also state regulations. Thus, if the survival of the household cannot be separated from state rules and obey them, then complying with these rules is obligatory.

\section{Conclusion}

Marriage registration is more firmly and specifically stated in Article 55 and Article 56. Article 55: (1) Every marriage, whether for residents who are Muslim or other religions, must be recorded. (2) Marriage registration for residents who are Muslim as referred to in paragraph (1) is carried out by marriage registrar employees at the District Religious Affairs Office. (3) The registration of marriages for residents of other religions as referred to in paragraph (1) is carried out by officials of the Regency/Municipal Population and Civil Registry Office. (4) The marriage registrar at the District Office of Religious Affairs shall record the marriage on the Marriage Certificate and issue the Marriage Certificate Quotation. (5) The Civil Registration Officer shall record marriages on the Marriage Certificate Registry and issue a Marriage Certificate Quotation. (6) Data on the results of marriage registration must be submitted by the District Office of Religious Affairs to the Regency/Municipal Population 
and Civil Registry Service within 10 (ten) days after the marriage registration is carried out. Article 56: Marriage registration as referred to in Article 55 also applies to: a) marriages determined by the court/Shari'ah Court; b) marriages of foreign nationals conducted in Aceh at the request of the foreign nationals concerned.

\section{References}

Abdurrahman. (1995). Compilation of Islamic Law in Indonesia, cet.II, (Jakarta: Akademika Pressindo).

Aceh Qanun No. 6 of (2008) concerning the Registration of the Implementation of Population Administration

Achmad Ali. (2009). Revealing Legal Theory and Justice Theory, (Jakarta: Kencana).

Achmad Maulana. (2011). Popular Scientific Dictionary (Yogyakarta: Absolut).

Ahmad Rofiq. (2011). Renewal of Islamic Law in Indonesia, (Yogyakarta: Gema Media).

Ahmad Taqiyah. (1999). Mashadir al-Tasyri' al-Islami, (Lebanon: Muassis al-Kitab alTasqofiyah).

Ahmad, Basyir. (1977). Islamic Marriage Law (Yogyakarta: Kencana).

Ali al-Jurjani, al-Ta'riifaat. (1985). (Beirut: Daar al-Kitab al-Arabi).

Al-Jazairi, Abd. Al-Rahman. (1969). Kitab al-Fiqh 'ala al-Madzahib al-'Arba'ah (Egypt; alMaktabah al-Tijariyyah).

Al-Mahalliy, Jalal al-Dien, Sharh Minhaj al-Thaālibin (Egypt, Daār ihyai al-Kutub al-Kubra, tt).

Al-mughniyah, Muhammad Jawad. (1999). Fiqh al-Imaām ja'far al-shadī̄q (Iran: Muassasah Ansariyah).

Al-Thahanawi. (2005). Mu'jam al-Isthilahaat al-Ulum wa al-Funun, (Beirut: Daar al-Ma'rifaah).

Amir Syarifuddin. (2009). Islamic Marriage Law in Indonesia: Between Fiqh Munakahat and Marriage Law, (Jakarta: Kencaran Prenada Media Group, cet.III).

Amir Syarifuddin. (2009). Ushul Fiqh, Volume 2, (Jakarta: Kencana Prenada Media Group).

Amir, Syarifuddin. (2007). Islamic Marriage Law in Indonesia, (Jakarta: Kencana).

Andi Hamzah. (1986). Legal Dictionary, (Jakarta: Ghalia Indonesia).

Ath-Tahir al-Azhar. (2008). al-Madkhal Ila Muwaththa 'Malik bin Anas, (Kuwait: Maktabah ash-Syu'un al-fanniyah).

Berg, Bruce L. (2001). Qualitative Research Methods For The Social Science (Boston; Allyn and Bacon).

Bogdan, Robert C. \& Sari Knop Biklen. (1982). Qualitative Research For Education (London: Allyn and Bacon, Inc).

Djmaan Nur. (1993). Fiqh Munakahat, (Semarang: Toha Putra).

Dodi Ahmad. (2008). Marriage Siri Yes or No, (Jakarta: Lintas Pustaka).

Do'i, Abd. Rahman.(2002). Complete Explanation of Allah's Laws (Shari'ah) (Jakarta; Rajawali Press).

Dr. H. Zulfikar Ismail. (2021). Director of Al-Muslimun Integrated Dayah Education, Interview, Lhokseumawe, 21 July.

Drs. Asnawi. (2021). Head of Islamic Community Guidance, Ministry of Religion, North Aceh Regency, Interview, 25 August.

Faisar Ananda arfa. (2010). Islamic Law Research Methodology (Bandung: Cita Librarian Media Perintis, Cet.1).

Fatimah. (2021). the perpetrator married a wild qadhi, interview 3 June.

Hadi, Sutrisno. (1998). Research Methodology, (Yogyakarta: ANDI Press, volume 2).

Happy Susanto. (2010). What's the Luck Sirri's Marriage, (Jakarta: Visimedia).

Hasan Alwi. (2009). Big Indonesian Dictionary, Third Edition (Jakarta: Balai Pustaka).

HMHasbi Umar. (2007). Contemporary Fiqh Reasoning, Cet. I, Jakarta: Gaung Persada Press). 
Ibn al-Hummam. (1970). Sharh fath al-Qaādir, (Cairo: Musthaāfa al-Babiy al-Halabiī).

Imam Malik. (1988). Al-Muwattha' Imam Malik, Takhrij By Muhammad Ridwan Sharif Abdullah Bab An-Nikah (Beirut: Dár al-Kitab)

Indonesia Dictionary from the Ministry of National Education, Fourth Edition (Jakarta: PT Gramedia Pustaka Utama, 2013).

Jalaluddin Abdurrahman bin Abi Bakr al-Suyuthi, Al-Asybah wa Al-Nazair (Surabaya: AlHidayah, tth.).

John Rawls. (1971). A Theory Of Justice, Original Edition, Harvard University Press Cambridge, Massachusetts London, England).

Juhaya S. Praja. (2011). Legal Theory and Its Applications, (Bandung: Setia Pustaka).

Julius Stone. (1965). Human Law and Justice, (California USA: Stanford University Press).

K. Bertens. (1999). History of Greek Philosophy (Yogyakarta; Kanisius).

Kanti Pamungkas Sari, Tohirin, The Impact of Siri Marriage on the Social Status of Women and Children (Social Analysis of Cases in Magelang Regency) (Final Research Report, University of Muhammadiyah Magelang, 2013).

Khanifah, Criminal Sanctions for Sirri Marriage in the View of NU and Muhammadiyah Alama, Analysis of Maslahah Mafsadah, (Surabaya: UINSA Postgraduate Program, 2015).

Khoiruddin Nasution, The Status of Women in Southeast Asia: A Study of Contemporary Muslim Marriage Laws in Jakarta and Malaysia (Jakarta: INIS, 2002).

Kontjoroninggrat, Community Research Methods, (Jakarta: Publisher PT Gramedia Pustaka Utama, 1997).

Law No.1 of 1974 concerning Marriage

Laws and regulations:

Lukman A. Irfan, Marriage, (Yogyakarta: PT Pustaka Insani Madani, 2007).

M. Solly Lubis. (2012). Philosophy of Science and Research (Jakarta: Publisher PT Sofmedia).

M. Sujari Dahlan. (1996).The Phenomenon of Siri Marriage (How Their Position According to Islam) Cet.I, (Surabaya: Progressif Library).

Masri Singarimbun and Sofyan Efendi. (1989). Survey Research Methods, (Jakarta: LP3ES).

Miles, MB \& Huberman. (1984). AM Qualitative Data Analysis, (Beverly Hills, Calif, Sage).

Ministry of Education and Culture. (1994). Big Indonesian Dictionary. (Jakarta: Balai Pustaka), 463.

Ministry of Religion of the Republic of Indonesia Directorate General of Islamic Institutions Section of the Project for Increasing Religious Personnel of Religious Counselors in 2002 Technical instructions for functional positions of Islamic Religious Counselors Cet.III, (Jakarta: Ministry of Religion of the Republic of Indonesia, 2002).

Mohd. Idris Ramulyo. (2006). Marriage Law, Inheritance Law, Procedural Law of Religious Courts and Zakat According to Islamic Law, (Jakarta; Sinar Graphic).

Mrs. Mawar. (2021). Interview, Lhoksukon, 27 July.

Munir Fuady. (2010). Dynamics of Legal Theory, (Bogor: Ghalia Indonesia).

Muslim Ibrahim. (2009). "The Aceh MPU Decision, Number 02 of 2009, Fatwa on the Law of Illegal Marriage was enacted on July 16.

Nasution, S, Qualitative Naturalistic Research Methods, (Bandung: Tarsito, 1987).

Nawawi Hadari. (1987). Social Research Methods, (Yogyakarta: Gajah Mada University Press).

Neng Djubaidah. (2010). Marriage Registration and Unregistered Marriages, Jakarta: Sinar Garfia).

Paul Edward and Lewis Mulfrad Adams. (1965). Webster World University Dictionari, Publishters Company inc, Washington DC).

Quran and its Translation. (2003). (Bandung: CV Publisher Dipegonegoro).

Raghib al-Isfahani. (2005). Mufradaat alfadzil Qur'an, (Beirut: Daar al-Ma'rifah). 
Ratna Julita. (2010). Juridical Study of Marriage Through Liar Qadhi (Research Study in Aceh Besar Indrapuri District) (Journal of Law, Sheikh Kuala University Banda Aceh).

Rusjdi Ali Muhammad and Khairizzaman, Constellation of Islamic Sharia in the Global Era, Aceh Islamic Sharia Service.

Salim, Syahrum. (2007). Qualitative Research Methodology, (Bandung: Cita Pustaka Media).

Salim. (2012). Theory Development in Legal Studies, (Jakarta: Raja Grafindo Persada Publisher).

Satria Effendi. (2004). Contemporary Family Law Problems, Jakarta: Research and Development Ministry of Religion RI, Jakarta).

Sayyid Sabiq. (1992). Fiqh as-Sunnah Cet. I Juz II, (Beirut Lebanon: Dár al-Kitab).

See M. Thobroni, Aliyah A. Munir. (2010). Reaching Blessings by Getting Married, (Yogyakarta: Pustaka Marwa).

See. Salim and Sahrum. (2007). Qualitative Research Methods, (Bandung: RIneka Cipta).

Shaifuddin Fuady. (2018). Government Agency Performance Accountability Report (LAKIP)

Office of Religious Affairs, Lhoksukon District, North Aceh Regency in 2020 (KUA Kec. Lhoksukon.

Soerjono Soekanto and Sri Mamudji. (1986). Normative Legal Research A Brief Overview, (Jakarta: CV Rajawali Publisher).

Soerjono Soekanto. (1983). Factors Affecting Law Enforcement, (Jakarta: Raja Grafindo Persada).

Soerjono Soekanto. (1983). Factors Influencing Law Enforcement (Jakarta: Raja Grafindo Persada).

Soerjono Soekanto. (1982). Introduction to Legal Research, (Jakarta: UI-Press, Salemba).

Sugiyono. (2006). Educational Research Methods (Bandung: ALfabeta, Juz. II).

Suharsimi Arikunto. (2002). Research Procedure A Practical Approach, (Jakarta: Rineka Cipta, Cet.1).

Sutan Remy Sjahdeini. (1993). Freedom of Contract and Balanced Protection for the Parties in Bank Credit Agreements in Indonesia, (Jakarta: Indonesian Bankers Institute).

Syamsul Bahri. (2012). Implementation of Marriage Registration in Medan Labuhan City District (Thesis: UIN-SU Medan).

Taqiyuddin Abi Bakr bin Muhammad al-Husaini. (1978). al-Hism ad-Dimasqi Asy-Syafi'i, Kifayah al-Akhyar (Semarang: Toha Putra, juz II).

Tengku Muhammad. (2009). Islamic Justice and Procedural Law (Bandung: Alumni).

Tihami. (2006). Jurisprudence Munakahat Study of Marriage Jurisprudence, (Bandung: Rafika Aditima).

Uber Silalahi. (1999). Research Methods and Methodology, (Bandung: Bina Budaya).

Zamakhsyari. (2013). Theories of Is

lamic Law (Medan: Cit

aputra Media Perintis). 